\title{
ARTICLES
}

\section{A STUDY TO ASSESS THE EFFECTIVENESS OF STRUCTURED TEACHING PROGRAMME ON KNOWLEDGE REGARDING ANTENATAL EXERCISES AMONG PRIMIGRAVIDA WOMEN VISITING OUTPATIENTS DEPARTMENTS OF SELECTED HOSPITALS IN JAIPUR}

Mr. Hemendra Parashar* | Mrs. Varsha Upadhyay** | Dr. Rajendra Prasad Sharma*** | Mrs. Kalpana Singh****

${ }^{*}$ Assistant Professor at Mahatma Gandhi Nursing College, Jaipur, Rajasthan, India.

**Assistant Professor at Mahatma Gandhi Nursing College, Jaipur, Rajasthan, India.

***Associate Professor at Mahatma Gandhi Nursing College, Jaipur, Rajasthan, India.

**** Assistant Professor at Tagore Nursing College, Jaipur, Rajasthan, India.

DOI: http://doi.org/10.47211/trr.2020.v06i01.001

Received $10^{\text {th }}$ February 2020, Accepted $5^{\text {th }}$ March 2020, Available online $25^{\text {th }}$ June 2020.

\begin{abstract}
Pregnancy is usually a serene time of unparalleled joy and expectation in a woman's life. However, sometimes it can be complicated by illnesses or medical conditions. Although only 10-30\% of the mothers seen in antenatal period can be classified as high risk they account for $70-80 \%$ of perinatal mortality and morbidity. Exercise during pregnancy naturally makes Primigravida mothers to feel good both mentally and physically. Exercising increases the production of serotonin which makes us feel better emotionally. The more care taken by individual bodies means the better they function and this includes the period of pregnancy and birth. Exercise is likely to improve sleep, mood and energy level. It may also help reduce bloating and prevent gestational diabetes. Women who exercise during pregnancy may also get back into shape after the birth of their baby more easily. Gentle exercising in pregnancy leads to an easier pregnancy and less complications during labour.
\end{abstract}

Key words: Primigravida women, Structured teaching programme, Antenatal exercises.

\section{ABOUT AUTHORS:}

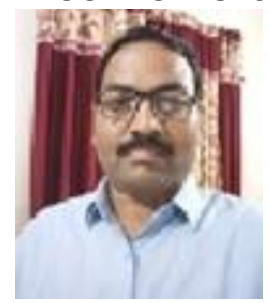

Author Mr. Hemendra Parashar is working as Assistant Professor in Mahatma Gandhi Nursing College, Jaipur, Rajasthan, India. He has attended and organised various National and International conferences.

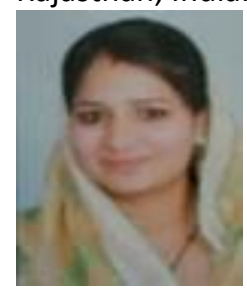

Author Mrs. Varsha Upadhyay is working as Assistant Professor in Mahatma Gandhi Nursing College, Jaipur, Rajasthan, India. She has published papers in national and International Journals.

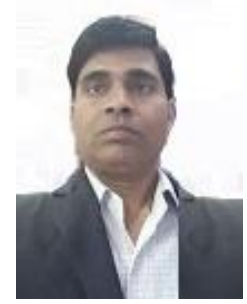

Author Dr. Rajendra Prasad Sharma is working as Associate Professor in Mahatma Gandhi Nursing College, Jaipur, Rajasthan, India. He has published papers in national and International Journals. He has attended and organised various National and International conferences and has given extensive lectures. 


\section{ARTICLES}

\section{INTRODUCTION}

Pregnancy is a beautiful experience which can be made more enjoyable with little care. Pregnancy is the state of carrying foetus inside the uterus by a woman from conception to birth. It is a normal physiological phenomenon which needs love and care. Antenatal period begins with conception and continues to birth. ${ }^{1}$

Antenatal care is essential until the birth of the baby. It aims at promotion and maintenance of physical and mental health of the mother during pregnancy, labour and puerperium. It also has the objective of preparing the mother for labour, puerperium and child care. Additionally, it helps to diagnose the abnormalities early and save life and improve health of mother and the baby. Antenatal care focuses on well-balanced diet, rest \& sleep, personal hygiene, antenatal check-ups and antenatal exercises. 2

Maternal benefits appear to be both physical and psychological in nature. Many common complaints of pregnancy, including fatigue, varicosities and swelling of extremities, are reduced in women who exercise. Additionally, active women experience less insomnia, stress, anxiety and depression. There is some evidence that weight-bearing exercise throughout pregnancy can reduce the length of labour and decrease delivery complications. An argument for public health is that women who incorporate exercise into their routine during pregnancy are more likely to continue exercising postpartum. ${ }^{3}$

\section{NEED FOR STUDY}

Benefits of exercise to healthy, pregnant women have been greatly appreciated, it helps in tolerating labour pain emotionally and physically, increases muscular strength decreases chances of unhealthy weight gain, quicker recovery from childbirth to pre-pregnancy weight, reduces incidence of haemorrhoids, varicose veins, backache, and fatigue causations. ${ }^{4}$

\section{OBJECTIVES OF THE STUDY}

1. To assess the knowledge regarding antenatal exercises among primigravida women.

2. To develop and administer structured teaching programme on Antenatal exercise for the primigravida women.

3. To assess the effectiveness of structured teaching programme on knowledge regarding antenatal exercises among primigravida women.

\section{HYPOTHESIS}

H1: There is significant difference between the pre-test and post-test levels of knowledge of primigravida women on antenatal exercises

H2: There is significant association between post-test level of knowledge and selected demographic variables.

\section{RESULT}

The collected information was organised and presented in four parts: Part I, Part II, Part III and Part IV.

Part I: Description of socio-demographic characteristics of the sample.

Part II: Assessment of pre-test knowledge of the primigravida women regarding antenatal exercises.

Section A: Assessment of the level of pre-test knowledge of primigravida women.

Section B: Area wise mean, SD and mean percentage of pre-test knowledge scores.

Part III: Evaluation of the effectiveness of the STP on antenatal exercises among primigravida women.

Section A: Comparison of level of knowledge of primigravida women in pre-test and post-test.

Section B: Area wise effectiveness of the STP.

Section C: Testing of Hypothesis.

Part IV: Association between post-test knowledge scores of primigravida women regarding antenatal exercises and their selected socio-demographic variables. 


\section{ARTICLES}

Table - 1: Frequency and percentage distribution of socio-demographic characteristics of the sample

$\mathrm{N}=60$

\begin{tabular}{|c|c|c|c|}
\hline Head of variable & Variables & Frequency & Percentage (\%) \\
\hline \multirow[t]{3}{*}{ Age } & $19-20$ years & 6 & $10 \%$ \\
\hline & $21-22$ years & 4 & $7 \%$ \\
\hline & 23 years and Above & 50 & $83 \%$ \\
\hline \multirow[t]{3}{*}{ Religion } & Hindu & 49 & $82 \%$ \\
\hline & Muslim & 9 & $15 \%$ \\
\hline & Christian & 2 & $3 \%$ \\
\hline \multirow[t]{4}{*}{ Education status } & Illiterate & 9 & $15 \%$ \\
\hline & Primary education & 37 & $62 \%$ \\
\hline & Secondary & 10 & $17 \%$ \\
\hline & Graduate & 4 & $6 \%$ \\
\hline \multirow[t]{3}{*}{ Occupation } & House wife & 45 & $75 \%$ \\
\hline & Private job & 12 & $20 \%$ \\
\hline & Government employee & 3 & $5 \%$ \\
\hline \multirow[t]{2}{*}{ Type of family } & Nuclear & 46 & $77 \%$ \\
\hline & Joint & 14 & $23 \%$ \\
\hline \multirow[t]{2}{*}{ Area of residence } & Urban & 38 & $63 \%$ \\
\hline & Rural & 22 & $37 \%$ \\
\hline \multirow[t]{3}{*}{ Monthly family income } & $10,000-20,000$ & 41 & $68 \%$ \\
\hline & $20,000-30,000$ & 12 & $20 \%$ \\
\hline & Above 30,000 & 7 & $12 \%$ \\
\hline
\end{tabular}

Part II: Assessment of pre-test knowledge of the primigravida women regarding antenatal exercises.

Section A: Level of pre-test knowledge of the primigravida women regarding antenatal exercises.

Table - 2: Level of pre-test knowledge of the primigravida women regarding antenatal exercises

$\mathrm{N}=60$

\begin{tabular}{|l|c|c|c|}
\hline Level of knowledge & Range of scores & Number of respondents & Percentage (\%) \\
\hline Very poor & $0-6$ & 22 & $37 \%$ \\
\hline Poor & $7-12$ & 25 & $42 \%$ \\
\hline Average & $13-18$ & 8 & $13 \%$ \\
\hline Good & $19-24$ & 5 & $8 \%$ \\
\hline Very good & $25-30$ & 0 & $0 \%$ \\
\hline Total & - & $\mathbf{6 0}$ & $\mathbf{1 0 0 \%}$ \\
\hline
\end{tabular}

Section B: Area wise mean, SD and mean percentage of pre-test knowledge scores of primigravida women.

Table 3: Area wise mean, SD and mean percentage of pre-test knowledge scores of primigravida women.

$\mathbf{N}=60$

\begin{tabular}{|c|c|c|c|c|}
\hline Knowledge area & Max. Score & Mean & SD & Mean \% \\
\hline General knowledge about antenatal exercise & 15 & 4.60 & 2.2 & $31.11 \%$ \\
\hline Benefits of antenatal exercise & 15 & 4.60 & 2.2 & $31.11 \%$ \\
\hline Total & 30 & 9.33 & 4.5 & $31.11 \%$ \\
\hline
\end{tabular}




\section{ARTICLES}

Part III: Evaluation of the effectiveness of structured teaching programme.

Section A: Comparison of levels of knowledge of primigravida women in pre-test and post-test.

Table - 4: Comparison of levels of knowledge of primigravida women in pre-test and post-test

$\mathbf{N}=60$

\begin{tabular}{|l|c|c|c|c|}
\hline \multirow{2}{*}{ Level of knowledge } & \multicolumn{2}{|c|}{ Pre-test } & \multicolumn{2}{c|}{ Post-test } \\
\cline { 2 - 5 } & No. of respondents & Percentage & No. of respondents & Percentage \\
\hline Very poor & 22 & $37 \%$ & 0 & $0 \%$ \\
\hline Poor & 25 & $42 \%$ & 0 & $0 \%$ \\
\hline Average & 8 & $13 \%$ & 1 & $2 \%$ \\
\hline Good & 5 & $8 \%$ & 31 & $52 \%$ \\
\hline Very good & 0 & $0 \%$ & 28 & $46 \%$ \\
\hline Total & $\mathbf{3 0}$ & $\mathbf{1 0 0 \%}$ & $\mathbf{3 0}$ & $\mathbf{1 0 0 \%}$ \\
\hline
\end{tabular}

Level of Knowledge of Primigravida Women in Pre-Test and Post Test

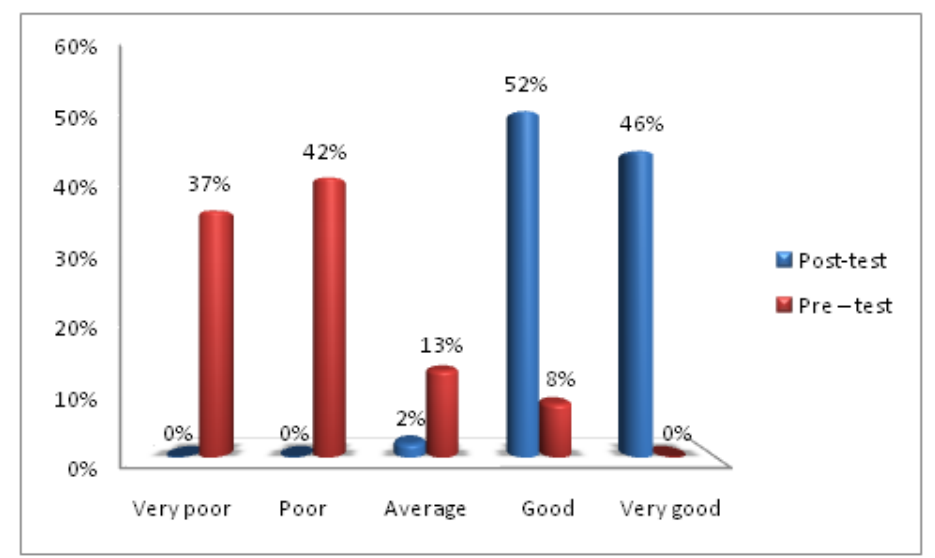

Figure - 1: Cylinder diagram showing comparison of levels of knowledge of primigravida women in pre-test and post-test.

Section B: Area wise effectiveness of the STP on antenatal exercises.

Table 3: Area wise mean, SD and mean percentage of knowledge scores in pre-test and post-test.

$\mathrm{N}=60$

\begin{tabular}{|l|c|c|c|c|c|c|c|}
\hline \multirow{2}{*}{ Knowledge area } & \multirow{2}{*}{ Max. score } & \multicolumn{2}{c|}{ Pre-test $\left(\mathbf{O}_{\mathbf{1}}\right)$} & \multicolumn{2}{c|}{ Post-test $\left(\mathbf{O}_{\mathbf{2}}\right)$} & \multicolumn{2}{c|}{ Effectiveness $\left(\mathbf{O}_{\mathbf{2}}\right.$ - $\left.\mathbf{O}_{\mathbf{1}}\right)$} \\
\cline { 2 - 7 } & Mean $\mathbf{S D}$ & Mean \% & Mean \pm SD & Mean \% & Mean \pm SD & Mean \% \\
\hline $\begin{array}{l}\text { General knowledge } \\
\text { about antenatal } \\
\text { exercise }\end{array}$ & 15 & $4.6 \pm 2.2$ & $31.11 \%$ & $11.83 \pm 1.48$ & $79.2 \%$ & $7.23 \pm 5.63$ & $48.1 \%$ \\
\hline $\begin{array}{l}\text { Benefits of antenatal } \\
\text { exercise }\end{array}$ & 15 & $4.6 \pm 2.2$ & $31.11 \%$ & $12.33 \pm 1.20$ & $82.2 \%$ & $7.73 \pm 11.18$ & $51.1 \%$ \\
\hline Total & $\mathbf{3 0}$ & $\mathbf{9 . 3 3 \pm 4 . 5 1}$ & $\mathbf{3 1 . 1 1 \%}$ & $\mathbf{2 4 . 2 1 \pm 2 . 3 7}$ & $\mathbf{8 0 . 7 2 \%}$ & $\mathbf{1 4 . 8 \pm 2 5 . 2 0}$ & $\mathbf{4 9 . 6 \%}$ \\
\hline
\end{tabular}

Comparison of Mean of Pre-Test and Post-Test Knowledge Scores of Primigravida Women. 


\section{ARTICLES}

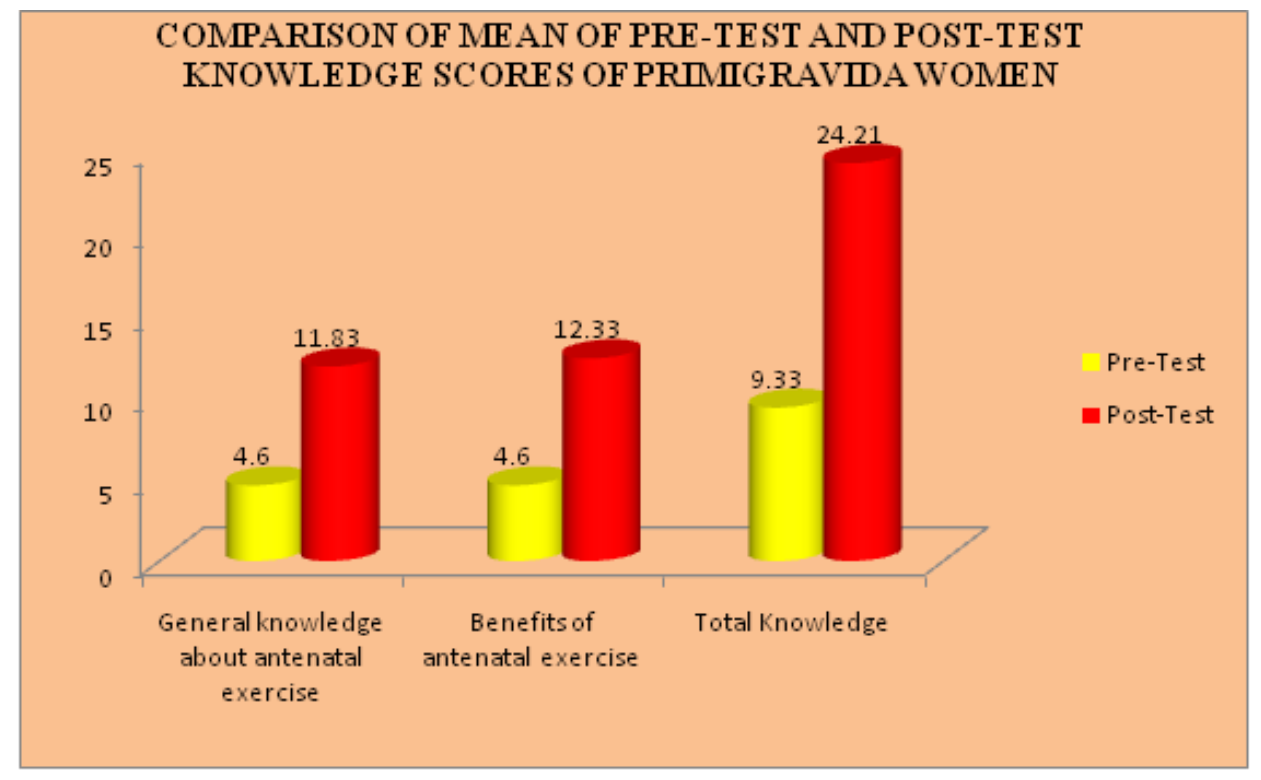

Figure 2: Cylinder diagram showing comparison of mean of pre-test and post-test knowledge scores of primigravida women.

\section{Section C: Testing of Hypothesis}

To evaluate the effectiveness of structured teaching programme, a research hypothesis was formulated.

Table 6: Significance of the difference between the pre-test and post-test knowledge scores of the primigravida women

$\mathrm{N}=60$

\begin{tabular}{|c|c|c|c|c|c|c|c|}
\hline Knowledge area & Test & Mean & SD & Mean diff. & SD Diff. & Paired t-value & Table value \\
\hline \multirow{2}{*}{$\begin{array}{l}\text { General knowledge about } \\
\text { antenatal exercise }\end{array}$} & Pre-test & 4.6 & 2.2 & \multirow{2}{*}{7.2} & \multirow{2}{*}{5.6} & \multirow{2}{*}{9.87} & \multirow{2}{*}{1.96} \\
\hline & Post-test & 11.8 & 1.4 & & & & \\
\hline \multirow{2}{*}{$\begin{array}{l}\text { Benefits of antenatal } \\
\text { exercise }\end{array}$} & Pre-test & 4.6 & 2.2 & \multirow{2}{*}{7.7} & \multirow{2}{*}{11.1} & \multirow{2}{*}{5.28} & \multirow{2}{*}{1.96} \\
\hline & Post-test & 12.3 & 1.2 & & & & \\
\hline \multirow{2}{*}{ Total } & Pre-test & 9.3 & 4.5 & \multirow{2}{*}{14.8} & \multirow{2}{*}{25.2} & \multirow{2}{*}{4.53} & \multirow{2}{*}{1.96} \\
\hline & Post-test & 24.2 & 2.3 & & & & \\
\hline
\end{tabular}

$* p<0.05$

Significant

The calculated values were much higher than table value (1.96). Hence, the $\mathbf{H}_{\mathbf{1}}$ stated is accepted. Findings reveal that the difference between mean pre-test $(9.3 \pm 4.5)$ and post-test $(24.2 \pm 2.3)$ knowledge scores of primigravida women were statistically significant at 0.05 level of significance $[t=4.53, p<0.05]$.

Similarly, the area wise difference between pre-test and post-test knowledge scores on antenatal exercises was highly significant. Mean of post-test knowledge scores in the area of 'General knowledge about antenatal exercise' $(11.8 \pm 1.4)$ is significantly higher than the mean of pre-test knowledge scores $(4.6 \pm 2.2)$ at 0.05 level of significance $(t=9.87, p<0.05)$. Mean of post-test knowledge scores in the area of 'Benefits of antenatal exercise' $(12.3 \pm 1.2)$ was significantly higher than the mean of pre-test knowledge scores $(4.6 \pm 2.2)$ at 0.05 level of significance $(t=5.28, p<0.05)$ 


\section{ARTICLES}

\section{REFERENCES}

1. Neelam Kumari, Shivani Sharma “Midwifery \& Gynaecological ", SK Vikas \&company, 2 ${ }^{\text {nd }}$ edition, 2010; Page No.145-147.

2. Nutan Pandit "Text book of Pregnancy" published by Rupa paper back, 1st edition, 2018, Page No: 60-83.

3. Amudha, Study on the effect of antenatal exercises among pregnant woman, Nightingale Nursing Times, vol 2 Issue 12, March 2007, Pp. 55 - 56.

4. Park. K. Text Book of Preventive and Social Medicine.17th ed. Jabalpur: M/S Banarsidas Bhanot Publishers; 2003.Pp 359-364. 